\title{
$\begin{aligned} \text { SOI: } 1.1 / \mathrm{TAS} & \text { DOI: } 10.15863 / \mathrm{TA} \\ \text { International } & \text { Scientific Journal }\end{aligned}$ Theoretical \& Applied Science
}

Sanobar Panjiyevna Tulaganova

Candidate of Philological sciences,

Institute of Uzbek Language, Literature and Folklore Academy of Sciences of Uzbekistan.

p-ISSN: 2308-4944 (print) e-ISSN: 2409-0085 (online) s.tulaganova@mail.ru

Year: 2018 Issue: 03 Volume: 59

Published: $16.03 .2018 \quad$ http://T-Science.org

SECTION 29. Literature. Folklore. Translation Studies.

\section{ISSUES OF AUTHOR'S PERSONALITY AND LITERAL TEXTURE}

Abstract: Personality of the author is a very difficult concept. Studying of the personality of the author in close interrelation with his works helps to comprehend those challenges, about which we didn't guess earlier. Accotrding to the founder of an autobiographical method Sainte-Beuve: "Any imaginative work is a speaking person, and it is impossible to divide the personality (author) from the work" [16, page 48]. Actually, an imaginative work of the author is the copy of his wordl-view. Article embraces a number of analysis methods. Information on the personality of Navoi are studied on biographic, historical-comparative and analytical methods.

Key words: author, personality, literal text, Alisher Navoi, biographic method, imaginative work, hero.

Language: English

Citation: Tulaganova SP (2018) ISSUES OF AUTHOR'S PERSONALITY AND LITERAL TEXTURE. ISJ Theoretical \& Applied Science, 03 (59): 123-127.

Soi: http://s-o-i.org/1.1/TAS-03-59-18 Doi: crossef https://dx.doi.org/10.15863/TAS.2018.03.59.18

\section{Introduction}

There are few authors in the world literature who can attract attention of the reader. Especially, gaining of authority in art and literature promotes changes and development of moral thinking of the nation. It can be seen in literature and life of people of Orient and West. Throughout five centuries Alisher Navoy attracts interest of scientists of the whole world.

\section{Materials and Methods}

Unambiguously, great poets as Alisher Navoy don't appear incidentally. First of all, adequate social-cultural environment, economical and political conditions are vital for this purpose. In spite of the fact that Navoi lived in the fifteenth century, he has taken the eternal place in the hearts of people. His creative personality and world-view are closely connected with moral-spiritual values, implemented by Amir Temur. Works of Alisher Navoi are very popular in the world. His books are translated into tens of foreign languages, including Persian, Italian, German, French, Dutch, Hungarian, Czech, Romanian, Polish, Indian, Turkish, English, Russian, Georgian, Azerbaijani, Turkish, Tatar, Ukrainian, Latvian and are repeatedly re-printed. Western travellers and officials staying in East in the 21st century often tried to take out copies of works of Navoi to their homeland. As a result, museums, libraries and private collections of Great Britain,
France, Germany, Italy gathered a number of works of Navoi. It This was mentioned in 1888 by English orientalist Ch.Riyo, at time of describing his catalogue in London $(13,273)$ European orientalists E.Bloshe, M.Buvat and E.Brown studied the personality of Navoi on the basis of his manuscripts $(5,505)$. Thus, since 21 century interest of European and Russian orientalists to the personality of the great poet had increased $(2 ; 18 ; 15 ; 10 ; 11 ; 14)$.

By the beginning of 21 century certain generation, which studied creativity and scientific heritage of Navoi had been shaped in the world. Such scientists as David de Vis, Bert Fragner, Kazauki Kubo, Mark Toutant, Alexander Popas, Nicholas Vomsley have conducted a number of researches on scientific heritage of Navoi, took part in international grant projects and propagandized activities of the great poet worldwide. Kazauki Kubo, professor of Kyoto University of Japan conducted a number of observations and researches on life and creativity of Alisher Navoi.

Kubo Kazauki has carefully studied a sphere, which was un-captured by the researchers of Navoi he analyzed activity of Navoi as a sponsor. Japanese scientist has emphasized humanity and generosity of the great poet. In his work "Sponsorship of Navoi" Japanese scientist has studied sponsorship of the poet, based on such works as "Makorim ul-akhlok", " Badoe al-vakoye", Baburnama, "Tarikhi Rashidi" and "Vakfiya". On the basis of various sources 
Kazauki Kubo could also define names of a great number of officials, who worked in Herat under the auspices of Navoi. Among them there were writers, calligraphers, musicians, artists - Navoi provided material and moral support to all of them.

According to Kubo, 11 people worked in private library of Navoi. Such interest and passion to Navoi's activity promoted development of separate science - Navoilogy.

By the way, in order that a literature can be shown in all its beauty - it requires social tranquility, economic stability and political freedom. Particularly, political unfreedom, ideological prosecutions complicate a creative path of authors. Thus, Husain Boykaro, who was in power for 38 years, was a close friend of Alisher Navoi sponsored him and played a significant role in his creativity. Similar to Amir Timur's role in Mirzo Ulugbek's destiny, Husain Boykaro has influenced Alisher Navoi creativity. Governance implemented at Timurides always inspired Alisher Navoi.

None of religion, sects, education or philosophy can not indicate on humiliation and insultence of humanity. Unfortunately, despite of that, it is possible to notice worldwide violations of human rights, utilization of people in slavery conditions. Injustice and violence doesn't recognize any religion, nation and races. And struggle against it by a feather evil ennobles an author. Alisher Navoy is also considered to be one of those devoted his life and creativity to this struggle. Fair government, love to people, continuous protection of interests was the main motive of his creativity. The main idea of each his work was appeal of Shah to conscience, justice and protection of interests of the people. According to historical data, Navoi by his nature was quiet, balanced, generous and fair person and this was reflected in essence of his creativity $(1 ; 6 ; 8 ; 3)$. It can be seen in "Matlai sa'dan" by Samarkandiy, "Ravza us-safo" of Mirkhond, "Makorim ul-akhlok" by Hondamir.

Amir Nizommiddin Alisher Navoi (1441-1501) is world renowned and has a status of outstanding Turkic poet, thinker and philosopher. His works are added to a treasury of world literature which promoted development of science, arts in the second half of the 15 th century at Timurids.

Long-term experience in governing and rich cultural heritage have been destroyed during Mugul invasion. In this regard revival of history and philosophy of the Turkic people was very difficult. Even efforts by Timurids on recognition of Turkic language as a State language hasn't been carried out up to the end. Navoi has managed to revive Turkic (Uzbek) language in the world of literature and could organize office-work in the state in one language. Alisher Navoi has finished up the work which Timur couldn't carry out, he managed to elevate the status of Turkic language to the state language.
Majesty and merit of Alisher Navoi in the history of nation are measured not only by the fact that he was a great poet only. As great he was in poetry, so developed he was in science. Still his works in the field of linguistics, history and sufism such as "Muhokamatul-ul-lug'atayn" (Studying of language) "," Mezonul ul-avzon" (weight) and "Nasoyim-ul-mukhabbat" (Love wind) are not analyzed completely. Greatness and personality of Alisher Navoi, his style had strongly differed from coeval writers. His ability to inform a reader on sincere passion of the hero, manifestation of godlike power in soul of the hero strongly differed him from others. It would not also be exaggeration if we tell that these distinctions have provided greatness to Navoi.

Any work of art is an inner world of the author, a spiritual kingdom, an independent state. This state has own culture, laws, orders and the principles. As the work of art is a certain state, naturally, it will have the territory and borders. And atyle used by the author, symbolical designations and metaphorical means are peculiar "lock" of this state. As soon as the reader correctly understands used "trick" and finds keys to conditional "lock" - only then work crosses its conditional border.

In most cases, reading any work we think of a plot, its heroes, we analyze and we criticize, but for some reason we forget about the personality of the author and his life. Writer is also a personality, alivebeing, biological and social component. Studying essence of works of Navoi, we notice versatile shades of personal experiences of the author in them. In particular, scientists have noted that we can evidence similarity between the hero prince Farrukh and the poet in the dastan "Sa'bai-sayyor". In this regard spiritual worry in works often coincide with personal moods of the poet" $(9,71)$. Having learned that Farrukh's beloved is also loved by his close friend, the prince refuses his love and decides to live his life alone. Such desperate gesture remains unnoticed by his friend. On the basis of such small details we can clear up some unknown moments of life of Navoi in regards of his marriage.

French scientist P.Valerie noted that "value of the literary text consists in ability to interpret each hero separately". "The text is a double system of a language created by an author" $(12,122)$. Eventually, it is necessary to consider psychology of the author behind each used word. For the due analysis of works of Alisher Navoi, they should be studied in a compartment with the period of life of the author. Main base of the literary text is a word. Navoi divided the word into two types - prose and poetry. Traditionally he put poetry (poems) above the prose. Because prose - is a chaotically combination of words, and poetry -ordered combination. The same was followed by Nizamy as well. Navoi supported efforts of Nizamy and promoted further development 
of his potential. Husrav Dekhlavy didn't consider the word as a backbone of the literary work. In this regard hence there is no uniform opinion on prose and poetry.

In "Hayrat-ul-Abror" Navoi had also put forward a number of theses concerning a role of a word. 1) definition of human aspect; 2) detection of moral qualities of a person; 3) establishment of advantages of poetry in prose. Knowing peculiar specifics of prose, and realizing ample opportunities concerning poetry, unambiguously, Navoi referred to prose for expression of a certain context and purpose. Speaking about a person, Navoi notes that a person differs from an animal by his ability to speak, however, it is not possible to call each speaking human-kind a person. He writes that the main symbol of mankind is a belief, i.e., conscience. Navoi noted that the word has to be used for good, noble purpose and if the word is used for evil motives, it can cause disaster, and a person using words in this purpose is not a Muslim. Spiritual wealth, morality, education is the main traits of Naoi's character which made a backbone of his works.

Navoi has such saying: "Though most of people have appearance of the person, most of them has no humanity... It is not necessary to be surprised of that. In any city there are few people, both physically and spiritually, worth this honor. Others, notwithstanding apperance, are deprived of this status". Conspirancy, gossips, violence - all these acts are made by means of the word. By means of words people use various ways for evil acts. The word has a magic force, both to kill and to revive a person. Word can destroy or prosper a country, word can revive great causes and also can serve origination of crimes. For this reason, poet constantly emphasizes a need for care and importance for selection of words.

Navoi considers that achievements of a person, first of all, depend on himself. Id est, if the person could subordinate the greed - a basis of negative virtures, he can follow a way to perfection though this way will not be easy. Therefore, bravery for Navoi is not a victory over a lion in a cage, but restraint of the greed living within the person.

The first prosaic works of Navoi "Hamsat ulmutahayyirin", "Holoti Pakhlavon Muhammad", "Holoti Sayeed Hasan Ardasher" have been ordered in Turkic language in which, besides description of the personality of outstanding scientific contemporaries such as Zhamy, Pakhlavon Mukahmmad, Sayeed Hassan Ardasher, poet lays initial foundations to the styles of prose. Navoi colourfully shows his ability to reveal a personality. Common feature, uniting these works, is creation in the spirit of Orient Renaissance. In "Holoti Sayiid Ardasher" there are such words - "Officialism is alike alcoholism. However it differs from wine dependence. Drunk person can not control his words and acts. As a result, he can offend people, can make silly acts. After sobering up people repent from their actions. However such repentance lasts one day or certain time. And alcoholism of officialism lasts consequent staying in a designation. If a person controls his deeds after appointment - it is good and if he loses a sense of reality, then it can end deplorable, he can make many foolish deeds". In due time Navoi worked in high designations, nevertheless, it never stopped him thinking about people and wellbeing of the country and nation. He always fulfilled his duties honestly and frankly. The allocated ideology of all works of Navoi always distinguished him from other writers. Navoi served people with not his works only, he implmented practical deeds.

Fact that Navoi had unusual talent can be proved when comparing with outstanding poets of the world. If Firdausi has written "Shakhnama" in 30 years, Nizamy his "Hamsa" in Azerbaijani language in 30 years, Husrav Dehlaviy his "Hamsa" in 6-7 years, Navoi writes "Hamsa" in 2 years. According to historical data, Hussein Boyqaro noted that a royal work of Navoi had been written in only 6 months.

While serving in high position at Husayna Boykaro, Timurid dynasty, Navoi served as an counsellor to the Shah (King) in fair and honest government. When he ruled Astrabod, he has made efforts in development and prosperity of the city and always acted fairly. By character Navoi would not be compared in love and mercy, generosity and modesty. This can be proved by dozens of examples in "Makorim ul-azlok" of Hondamir. Facts that Navoi always compared himself to "earth", his generosity with prisoners, even his attitude towards ants hooked to his clothes - he always carried them to their hill - all this is described in Hondamir's work. When Navoi is appointed to a high position at the Palace, stamping ceremony was carried out. On this event, being a main Amir (minister), Navoi signs the document at the very bottom of paper where it is impossible to put a seal - it demonstrates his extraordinary modesty and humanity.

Alisher Navoi was owner of huge territories. In 1481 he gives up his lands - hands over the property and creates a charitable fundation. Income from the property - buildings in Hirat, Ikhlosiya madrasah, 24 shops, 3-4 markets and huge acreage has been directed to educational institutions, inns for wandering and dervishes, to pilgrims, for satisfaction of needs of poor, orphans and persons in need. Main part of the income had been aimed to the development of science and literature. It is historically proved that tens of scientists have been completely involved in the scientific activity by material support of Navoi. A special attention was paid to the people writing historical books and fine arts masters. Under the personal initiative and personal assets of Navoi Halosiya, Shifoiya and Nizomiya madrasahs were constructed in Heart, 
where famous scientists have delivered lectures. All his life Navoi cared for the welfare of people and it is considered tobe one of those writers, who have devoted life to this. Special reservoirs for the people needing water have been biult under his supervision, 16 bridges and 2 flood dams were built - all these constructions served for the welfare of simple people.

Mahomed Haidar in his "Tarikhiy Rasheed" notes generosity of Navoi to people of science and art - "Due to efforts of Navoi outstanding scientists appeared from among simple during this period. Having saved huge wealth, he allocated funds for the needs of people as charity with no hesitation. As per his abilities Navoi assisted persons in need and scientist. Income from property he had spent for charity for the benfit of the country. About sense of his life Navoi writes: "I have seen many difficulties, but the most difficult was to fulfill a civil duty - that is the hardest work - a sense of responsibility in front of the people and nobody has the right to forget about it".

Harry Dick, Canadian scientist studying creativity of Alisher Navoi writes that "We need real artists for upbringing of the nation... True development does not happen from outside, it exists in the hearts of people. We are in need, we dream that such poets as Navoi would speak in our language, from whom we could learn much and take example".

A.Navoi was not only a poet, he also was an outstanding politician and philosopher of his period. As a historian Alisher Navoi has written such works as "Tarikhi mulki azham" (History of Persian Shahs) and "Tarikhi anbiyo va hukamo". In his religiously motivated works as "Nasoyim ul-mukhabbat", "Vakfiya", "Qirq Hadis" (Forty Hadis), "Munshaot", etc. he described various spheres of social political issues of his time.

In his "Majolis un-nafois" Alisher Navoi tells about 459 people of various professions, who were engaged in creativity, and carried out analysis of positive and negative aspects of their works. Navoi's "Mukhokamat ul lagatayn" serves as a proof of a role and contribution of the poet to the literature and development of cultural life of people of that time. Except all, this work is a bright heritage of scientific prose of Alisher Navoi. In "Mukhokamat il lagatayn" Navoi repeatedly emphasizes that this work is made on background of rich traditions of works in ancient Uzbek and Persian languages.

It is not a secret that some unresolved questions in the science were the reason that the personality of the author remains still un-studied. Studying author's personality in literature had been started in Europe in the first half of the last century. At the same time, as we speak about author's personality, it will not be superfluous to pay attention to a truth in regards to author's personality, since each author has personal character. So far, carrying out parallels between a work and a personality of an author was not encountered. Another fact that one of the main problems in navoilogy - is studying of creativity of authors of other nation and religion on the basis of own views and principles.

It is proved today that studying of creativity of Navoi by Russian scientists Bartold and Bertels have been carried out unilaterally, separately from the author and life period, which resulted corresponding conclusions. It is obvious that writers express their opinions in works. Id est literal text serves as a bridge between the author and a reader. Behind each satr and misra (sentence) of Navoi there are poet's condition and mood of the people - and one should not ignore it. It is expedient to remember research of the British scientist R. Nicolson "Tasavvufda ilokhiy shakhsiyat" (Sacred personality in Sufism). Topics devoted to Mansur Halloj, Gazzoliy and Rumiy awaken discussions among readers. Muslim scientist Afify, who has written a preface to this book, having seen as "author combines efforts and concept of personality based on Christian belief and tries to find alternative in Sufism. However, there is a big difference between Christian points of view and Islamic". It is impossible to forget that we faced insufficient attention towards works, which stipulate unity of Alisher Navoi's personality and views of his heroes. It is important to note that it is an actual task for scientists - Navoilogists.

Artistic image is a self-expression by means of other person. A writer is in the relation with the image on the basis of his temperament, character, nationality and esthetics. As multi-sided and full will be a author's personality, so his heroes will be complicated in character. Besides that creation of true character is managed by free, honest and internally unite authors. Life and sociaty approach will be enough for such author. And he will have a apprehension towards his time. The ideal character can be created by spiritually full, physically free, spiritually steady and religiously stable author. Due to his outstanding qualities, Alisher Navoi could create his great works. And his awesome and bright heroes are peculiar "sparkles" and "I"s of the author.

Content of a difficult work can be compared to a nature. The analysis of texts indicates the mastered skills of Alisher Navoi in the field of science. When we talk about poetic analysis, mostly ideology and discussion of sense, moderation, rhymes and art is generally understood. As the real analysis and interpretation demands judgment of interrelation of all components of work - sounds, accords, colourness and sense with condition and passion of author. Eventually, it is time proved that the atmosphere of time, condition of the period, passions of the society also influence the author, that is undoubtedly, is reflected in his works. Writers of the East show the world of passions by means of main characters. 


\begin{tabular}{|c|c|c|c|c|c|c|}
\hline Impact Factor: & $\begin{array}{l}\text { ISRA (India) } \\
\text { ISI (Dubai, UAE } \\
\text { GIF (Australia) } \\
\text { JIF }\end{array}$ & $\begin{array}{l}=1.344 \\
=0.829 \\
=0.564 \\
=1.500\end{array}$ & $\begin{array}{l}\text { SIS (USA) } \\
\text { PИНЦ (Russia) } \\
\text { ESJI (KZ) } \\
\text { SJIF (Morocco) }\end{array}$ & $\begin{array}{l}=0.912 \\
=0.207 \\
=4.102 \\
=2.031\end{array}$ & $\begin{array}{l}\text { ICV (Poland) } \\
\text { PIF (India) } \\
\text { IBI (India) }\end{array}$ & $\begin{array}{l}=6.630 \\
=1.940 \\
=4.260\end{array}$ \\
\hline
\end{tabular}

Esthetically ideal perfect hero of Alisher Navoi, first of all, consists of aspiration of the author to find own "I" in life.

Basing from the mentality and world-view, poet loads a literal sense and idea to his heroes. Imaginative characters - are reflection of author's "I", his ideological model, which reflects dreams and experiences of the author. Author's "I" has got more complicated structure than we think of it. Nation language, belief, values, traditions and customs of the personality of the author are reflected in him. We shouldn't forget that " biographers consider that the personality of the ordinary-looking author can not showcase his "I", in this regard history estimates only his work" (16, 48). Actually, key to understanding an essence of the work is author's life and destiny $(4,356)$.

\section{Conclusion}

Esthetic ideal is considered to be a historical category and every period has its own ideal. Esthetic ideal is an association of an esthetic and artistic tact of author, his dreams and desires.

Each reader understands, realizes, feels and interprets an inner world of Alisher Navoi on the basis of own opportunities and apprehensions. In this regard, unique creations of the great poet and philosopher Alisher Navoi for centuries deliver spiritual pleasure, moral happiness, mind knowledge to the readers and also serve as a sacred astonichment and moral requirement.

\section{References:}

1. Abdullayev V. (1968) Navoi Samarqandda. Toshkent.

2. Bertels YE. (1965) Navoi i Jomiy. - Moskva.

3. Bobur. (1989) Boburnoma. - Toshkent.

4. Borev Y. (1981) Estetika. - Moskva.

5. Browne E. (1969) Literary History of Persia. Vol. III. - Cambridge.

6. Hayitmetov A. (1961) Navoi lirikasi. Toshkent.

7. Ibrohim Haqqul. (2014) Navoiga qaytish. 1, 2, 3-tomlar. - Toshkent.

8. Ishoqov Y. (1965) Navoining ilk lirikasi. Toshkent.

9. Isoqov Y. (1965) Alisher Navoining ilk lirikasi. - Toshkent.

10. Koprulu M. (1945) Cagatay edebiati. Islam ansklopedisi. 3 Cild. 24 cuz. - Istanbul.

11. Kopruluzade M. (1934) Turk dili ve edebiati hakkinda arastirmalar. - Istanbul.
12. Lotman Y. (1989) Struktura xudojestvennogo teksta. - Moskva.

13. Rieu Ch. (1888) Catalogue of the Turkish Manucripts in the British Museum..

14. Sa'diy A. (1940) Navoi ijodiyoti va o'zbek klassik adabiyoti taraqqiyotining yuksak bosqichi sifatida. - Toshkent.

15. Salye M. (1947) Kniga blagorodnix kachestv i yeyo avtor. - Toshkent.

16. Sent-Byov Sh. (1970) O. Literaturniye portreti. - M.

17. Sent-Byov.SH.O. (1970) Literaturniye portreti. - Moskva.

18. Sirojiddinov Sh. (2011) Alisher Navoi. Manbalarning qiyosiy-tipologik tekstologik tahlili. - Toshkent.

19. Yakubovskiy A. (1946) Cherti obshestvennoy i kulturnoy jizni epoxi Alishera Navoi. - Moskva. 